\title{
Othering and Selfing: Reading Gender Hierarchies and Social Categories in Michel Houellebecq's Novel Soumission
}

\author{
Wening Udasmoro \\ Universitas Gadjah Mada, Indonesia \\ Email: udasmoro@ugm.ac.id
}

\begin{abstract}
In literature, questions of the self and the other are frequently presented. The identity politics that gained prominence after the attack on the World Trade Center in New York on 11 September 2001 has occupied considerable space in this debate throughout the globe, including in France. One example of a novel dealing with the self and other is Michel Houellebecq's Soumission (2015). This article attempts to explore the processes of selfing and othering in this work. The politics of identity that seems to present Muslims and Islam as the other and French as the self is also extended to other identities and aspects involved in the novel. This article attempts to show, first, how the French author Houellebecq positions the self and other in Soumission; second, the type of self and other the novel focuses on; and third, how its selfing and othering processes reveal the gender hierarchy and social categorization of French society. It finds that the novel presents a hierarchy in its narrative through which characters are positioned based on their gender and sexual orientation, as well as their age and ethnic heritage.
\end{abstract}

Keywords: Gender; Social Categories; Islam; Soumission; Houellebecq

\section{INTRODUCTION}

The politics of otherness is important in interpersonal relations, and no group is immune to the othering process. The Polish sociologist Zygmunt Bauman, in his book Modernity and Ambivalence, wrote that otherness is a means for communally creating categories (Bauman, 1991, p. 75). These categories are generally created by dominant groups and applied to groups with less power. Zygmunt also explained, "Being a stranger means, first and foremost, that nothing is natural, nothing is given of right, nothing comes free." The construction of otherness involves the creation and propagation of stereotypes and clichés about minority groups and other outsiders.

In French society, Muslims have experienced this process of othering (Udasmoro, 2017). It cannot be ignored that Islam's history in Europe is one of invasion and conquest. The Crusades, which lasted for several centuries, contributed to the othering of Muslims by non-Muslim French people and vice versa
(Couvreur, 1998). These groups created stereotypes that exhibited their mutual lack of trust (Bowen, 2009). The Crusades, considered by Christians a holy war against Muslims, lasted in several phases. The first lasted from 1096 to 1099, during which Christians attempted to secure access to holy sites, as well as to defend Byzantine Emperor Alexius I and Constantinople from Turkish attacks. The second phase occurred in the twelfth century, albeit on a smaller scale. The third phase, which occurred during the thirteenth century, was known as the war against paganism. Meanwhile, during the fourth phase, almost all of Europe fell to the Ottoman Empire. In this phase, Islam and its culture spread widely throughout Europe.

Meanwhile, the rise of Islam in contemporary France is inseparable from French colonialism in countries across the Mediterranean, particularly Morocco, Tunisia, and Algeria (Zwilling, 2015). Following the independence of these countries 
in the 1960s, Maghrebi migrants introduced new dynamics to internal French politics. In 1956, a swathe of migrants entered France from Tunisia and Morocco. Meanwhile, in 1962 France saw an influx of Algerian migrants following the latter's independence (Kastoryano, 2004).

Today, it is thought that 3.5 to 5 million Muslims live in France, representing some 6 to 8.5 percent of France's population of 58.5 million. Of these, 2.1 million are French citizens. Approximately 70,000 to 110,000 of these are converts. Islam is the second largest religion in France, following Christianity (which includes both Catholicism and Protestantism); this number is also smaller than the number of French people who consider themselves atheist or irreligious. According to data from the National Institute for Statistics and Economic Studies (INSEE), unemployment among French-born citizens is $9.2 \%$, while unemployment among migrants is $14 \%$ (INSEE, 2005).

The presence of Muslims in France, with their economic, educational, and social backgrounds that differ from those of "native" French people, as well as their "foreign" Islamic culture and ideology, has led to polemics and othering. "Selfing" and "Othering" processes have been prominent in everyday life, as well as French politics and literature.

Following the terrorist attacks of 11 September 2001, the topics of Islam and Muslims have been increasingly common in French writing (Mustofa, 2016). This includes the novels Syngué Sabour, Pierre de Patience ("The Patience Stone") by Atiq Rahimi and 2084, La Fin du Monde ("2084, the End of the World") by Boualem Sansal. Both authors are immigrants currently living in France. Atiq Rahimi, who was born in Afghanistan, writes frequently about the lives of Muslim immigrants, including women living under authoritarian regimes in majority-Muslim countries (Sentana, 2016). Meanwhile, Boualem Sansal is an Algerian writer who writes frequently about Islam and Muslims. He received the Prix du roman arabe in 2012.

Another novelist who has frequently been the subject of discussion is Michel Houellebecq, a French author born in the overseas territory of Réunion and raised in Algeria (McAlpin, 2015). Where Maghrebi writers from outside France write about Islam as a non-French culture (Pramudita, 2013), allowing them to criticize it, Houellebecq wrote in his 2015 novel Soumission ("Submission") about the irony of living in Europe as new contestations occur as a consequence of migration. In doing so, he has literarily transformed non-Muslim French people from their real position as a majority into a marginalized group while simultaneously transforming Muslims from marginal to dominant (Mustofa, 2016). In this speculative novel, the author presents France as if it were under an Islamic regime.

Houellebecq's novel has drawn considerable criticism from various parts of the literary world. Soumission became a controversial novel because it touched on a sensitive issue, namely the position of Islam in France and the tensions between Islamic social practices and those considered "original" to France. Houellebecq's sixth novel, Soumission was praised by those who promoted French isolationism and criticized by those who disagreed with its apparent positioning of Islam (McAlpin, 2015). Houellebecq's caricature was on the cover of Charlie Hebdo magazine in Paris on 7 January 2015 the day these offices were attacked by two armed men and twelve people were killed; Houellebecq was soon placed in protective custody (McAlpin, 2015).

Much of the criticism of Houellebecq's work was rooted in disapproval of the views expressed by Houellebecq. Léger, for example, wrote of the concerns for rights in France, as well as Islam's development in contemporary France (Leger, 2015). Claude Pérez, meanwhile, focused on the contents of the novel, holding that it was not solely political, but also mediatic, presenting the author's views as presented through his use of media (Perez, 2012). This novel, with its oversimplification of political contestations in France, presented an irony of sorts. Numerous critical reviews, many of which were written by members of the inside group, were also published in newspapers, and Soumission thus found increased popularity among media consumers.

This article attempts to explore the issues of othering and selfing found in Soumission. The author is nota bene a Frenchman with narrative legitimacy in positioning Islam as faced by the people of France. Houellebecq's understanding of self and other are examined using a non-French perspective. This article examines, first, how the French author Houellebecq positions the self and other in his novel Soumission. Second, it questions what type of self and other is the focus of the novel. And third, it investigates how these selfing and othering processes reveal the gender hierarchy and social categorization of French society. 


\section{OTHERS IN THE NOVEL SOUMISSION}

Although Islam is the main topic of the novel, other specific entities are explored as well. These others are not monolithic. In the author's discussion of Islam, several categories are included. Aside from men and women, these categories also include several different ethnic groups, each of which is depicted with its own stereotypes. Among these stereotypes are those related to the relations between the three Abrahamic religions (Judaism, Christianity, and Islam). The narrator explains:

"Ah..." Il sourit de nouveau. "Pour les Juifs, c'est évidemment un peu plus compliqué. En principe la théorie est la même, le judaïsme est une religion du Livre, Abraham et Moïse sont reconnus comme des prophètes de l'Islam; il reste qu'en pratique, dans les pays musulmans, les relations avec les Juifs ont souvent été plus difficiles qu'avec les chrétiens; et puis, bien sûr la question palestinienne à tout envenimé (Houellebecq, 2015, p. 164).

"Ah...", he smiled again. "With the Jews, of course, things are somewhat more complicated. In theory, it's the same - Judaism is a religion of the Book, Abraham and Moses are recognized as prophets of Islam. In practice, though, relations in Muslim countries have often been more difficult than with Christians. And of course, the Palestinian question has poisoned everything (Houellebecq \& Stein, 2015, p. 128).

The area of historical questions is related to the historical situations, experiences, and memories shared by Muslims, Christians and Jews. These relations are continuously discussed because they are frequently the basis of political, social, and cultural problems (Mandel, 2014).

In regards to otherness, these three communities have a history of othering each other. Muslims, for example, have often used the term kafir (unbeliever) to refer to non-Muslims, while Jews have used the term gentile to refer to non-Jews (Heinsh, 2016). Meanwhile, Christians have frequently used the words pagan and heathen to refer to non-Christians. They use othering to exclude others from their groups and to delineate their own identities. This is shown in considerable detail in Soumission.

In the novel, Jews are shown as not having good relations with Muslims, as in the following quotation:
Là..." elle secoua la tête, dubitative, "là, je suis moins optimiste que toi. Quand un parti musulman arrive au pouvoir, ce n'est jamais très bon pour les Juifs. Je ne vois pas de contreexemple..." (Houellebecq, 2015, p. 111).

She shook her head, unconvinced. "I guess I'm less optimistic than you are. When a Muslim party comes to power, it's never good for the Jews. Can you think of a time it was?" (Houellebecq \& Stein, 2015, p. 85).

The text's depiction of Jews, as opposed to Muslims, also reflects the poor historical relations between Muslims and Jews, which have been exacerbated by the conflict between by Israel and Palestine (Mandel, 2014). However, in Soumission the focus is on Jews' otherness in their relations with the French people. This is the basis for concerns that anti-Semitism will become a problem if the National Front — a French conservative and nativist party - comes to power. In the novel, several characters feel themselves becoming othered by the rise of the National Front. The novel's Jewish characters, who were born and raised in France, feel some affiliation with other Jews, while at the same time feeling uncomfortable in an increasingly nativist and nationalistic France. This is shown below:

Ils ont passé des soirées ensemble, ils se sont monté la tête mutuellement, ils ne sont pas les seuls à partir, il y a au moins quatre ou cinq de leurs amis qui ont tout liquidé pour s'installer en Israël. J'ai discuté une nuit entière avec eux , sans parvenir à entamer leur détermination, ils sont persuadés qu'il va se passer quelque chose de grave en France pour les Juifs, c'est bizarre, c'est un truc qui leur vient sur le tard, à cinquante ans passés, je leur ai dit que c'était complètement con, que ça fait bien longtemps que le Front National n'a plus rien d'antisémite!... (Houellebecq, 2015, p. 110).

They stay in at night, working each other up - and they're not the only ones, they've got at least five other friends who've sold everything so they can move to Israel. I spent a whole night arguing with them, but they've made up their minds. They're convinced that something really bad is going to happen to Jews in France. It's weird, it's like a delayed reaction fifty years after the war. I told them they're being idiots, 
the National Front stopped being anti-Semitic a long time ago (Houellebecq \& Stein, 2015, p. 84).

In the above quote, it is apparent that the narrator attempts to convince his friends and colleagues not to leave for Israel, to which they intend to travel for fear of the National Front and Islam becoming a political force in France. In their reaction, it is apparent that leadership by Muslims and the nativist National Front are considered equivalent, despite their distinct identities. They fear both the National Front, known for its Islamophobia and anti-immigrant policies, as well as Islamic leadership, which is perceived as exclusive.

The characters, being demotivated by the main character, have their own reasons for remaining in France, which they consider their homeland.

"Mon frère et ma sœur peuvent continuer leurs études au lycée; moi aussi je pourrais aller à l'université de Tel-Aviv, j'aurais une équivalence partielle. Mais qu'est-ce que je vais faire en Israël? Je ne parle pas un mot d'hébreu. Mon pays, c'est la France" (Houellebecq, 2015, p. 111).

"My brother and sister can attend the French school, and I could go to Tel Aviv University. They'd take my credits. But what am I going to do in Israel? I don't speak a word of Hebrew. France is my country" (Houellebecq \& Stein, 2015, p. 85).

In this, a distinct form of nationalism involving "outsiders" is apparent. In the novel, the plot indicates the characters' love for France, despite their fears for a France ruled by anti-Semites. However, these phobias are not realized; they are limited to characters' imaginations. In this context, nationalism is not the nativist identity promoted by the rightist National Front, nor is it an Islamic one. The characters attempt to forefront an integral aspect of the French identity: its status as a republic.

\section{FEAR OF ISLAM IN THE LITERARY IMAGINATION}

In the novel, the French people are also distinguished ethnically from Maghrebis through an othering process. In the narrative, a Muslim named Ben Abbes is said to have won the election on a platform of shifting Europe's center of gravity towards the south (i.e. across the Mediterranean to Tunisia, Morocco, Algeria, and Egypt).

Le principal axe de sa politique étrangère sera de déplacer le centre de gravité de l'Europe vers le Sud; des organisations existent déjà qui poursuivent cet objective, comme l'Union pour la Méditerranée. Les premiers pays susceptible de s'agréger à la construction européenne seront certainement la Turquie et le Maroc; ensuite viendront la Tunisie et l'Algérie. A plus long terme, il y a l'Egypte- c'est un plus gros morceau mais ce serait décisif (Houellebecq, 2015, p. 165).

The main thrust of his foreign policy will be to shift Europe's centre of gravity towards the south. There are already organisations pursuing this goal, like the Union for the Mediterranean. The first countries likely to join up will be Turkey and Morocco, then later will come Tunisia and Algeria. In the long term, Egypt that would be harder to swallow, but it would be definitive (Houellebecq \& Stein, 2015, p. 128).

The countries are not mentioned by Houellebecq without a reason. Why is it that all of the mentioned countries have majority Muslim populations? These countries are not the only ones with high rates of migration to France; migration from Eastern European countries such as Romania, Bulgaria, and the former Balkan states is also considerable. Turkey, Morocco, Tunisia, Algeria, and Egypt are positioned as others in the novel for ideological reasons; these countries have transformed the dynamics of migration in France.

Migration in France has involved migrants from around the globe. According to data from the European Union, in 2015 France ranked third in the European Union in terms of immigration, behind Germany and the United Kingdom (before it left the European Union), with 363,869 immigrants that year (Eurostat Statistics Explained, 2017). Most traveled to France for economic reasons, as they believed it offered them greater economic opportunities. Others were fleeing political persecution. According to statistics released by INSEE, in 2008 some 11 million immigrants lived in France. Of these, 5.5 million were born in Europe, 4 million were born in the Maghreb, and 1 million were born in other parts of Africa; a further 4,000 were born in Turkey (Eurostat Statistics Explained, 2017). One must ask why, when most 
migrants in France were born in Europe, immigrants from the Maghreb are most frequently politicized and problematized. Ideological problems, as well as international incidents involving Muslims, have colored the dynamics of French society and literature.

Soumission also includes discussion of Saudi Arabia, with a specific focus on economic considerations. The novel's Ben Abbes, a Muslim candidate for French president and predicted election winner, is seen as gaining control over Europe with Arab money and promoting Arab interests. This is seen in the following quotation.

Ben Abbes, je suis convaincu, c'est de devenir à terme le premier président élu de l'Europe -d'une Europe élargie-, incluant les pays du pourtour méditerranéen. Il faut se souvenir qu'il n'a que quarante-trois ans-même si, pour rassurer l'électorat, il s'efforce de paraître davantage en cultivant son embonpoint et en refusant de se faire teindre les cheveux. Dans un sens la vielle Bat Ye'or n'a pas tort, avec son fantasme de complot Eurabia; mais elle se trompe complètement lorsqu'elle s'imagine que l'ensemble euro-méditerranéen sera, par rapport aux monarchies du Golfe, dans une position d'infériorité: on aura affaire à l'une des premières puissances économiques mondiales, et ils seront tout à fait en mesure de traiter d'égal à égal (Houellebecq, 2015, p. 165).

Ben Abbes's true ambition, I'm sure of it, is eventually to be elected president of Europe greater Europe, including all the Mediterranean countries. Remember, he's only forty-three - even if he cultivates a paunch and refuses to dye his hair. In a sense, old Bat Ye'or1) wasn't wrong with her fantasy of a Eurabian plot. Her great mistake was in thinking the Euro-Mediterranean countries would be weak compared with the Gulf States. We'll be one of the world's great economic powers. The Gulf will have to deal with us as equals (Houellebecq \& Stein, 2015, p. 129).

This fear is quite political. In the imagined world of the novel, there is considerable fear of Islam's influence on French social and political life. This fear is not limited to Islam, but also includes the Arab world, which is seen as seeking to dominate Europe.

This fear of Islam is also apparent in interactions with individual Muslims. When the narrator interacts with Arab people, fantasies emerge that they will cause trouble. The quote below shows how Arabs are viewed as fearsome entities within the novel's narrative.

Devant la porte de ma salle de cours- j'avais prévu ce jours-là de parler de Jean Lorrain-trois types d'une vingtaine d'années, deux arabes et un Noir, bloquaient l'entrée aujourd'hui ils n'étaient pas armes et avaient l'air plutôt calmes. Ils n'y avaient rien de menaçant dans leurs attitudes... (Houellebecq, 2015, p. 34).

When I reached my classroom - today I planned to discuss Jean Lorrain - there were three guys in their twenties, two of them Arab, one of them black, standing in the doorway. They weren't armed, not that day. They stood there calmly. Nothing about them was overtly menacing... (Houellebecq \& Stein, 2015, p. 23).

In this quote, the narrator's fear of Arabs is manifested. The statement "They weren't armed" vulgarly and stereotypically emphasizes that Arabs are usually armed. In the novel, Arabs and Islam are seen as two edges of a single, dangerous sword threatening French identity.

\section{OTHER MINORITIES AS OTHERS}

Aside from Muslims and Jews, other minorities are also positioned as others in the novel. These include the ethnic Chinese living in France. LGBT (Lesbian, Gay, Bisexual, and Transgender) individuals are also positioned as others, although the focus is on lesbian and gay groups.

Everyday stereotypes are reproduced in the novel's narrative. The importance is not the contestation of the actors motoring the narrative, meaning that the focus is not on the story but on the various types of discourses presented by its characters. When the narrator mentions some Chinese students, he presents his stereotypes about them. There is a social hierarchy constructed, one distinguishing between the brilliant French academic native from Western Europe - in the book, part of les populations authoctones d'Europe occidentale ("the indigenous population of Western Europe") - and the Chinese students whose narratives are suppressed. The following underscores the social hierarchy constructed through the narrative.

... un groupe de Chinoise, d'un sérieux réfrigérant, qui parlaient peu entre elles, et 
jamais a personne d'autre. Dès leur arrivée, elles allumaient leur smartphone pour enregistrer l'intégralité de mon cours, ce qui ne les empêche pas de prendre des notes sur de grands cahiers 21 x 29,7 à spirale. Elles ne m'interrompent jamais, ne posaient aucune question, et les deux heures passaient sans me donner l'impression d'avoir véritablement commence (Houellebecq, 2015, p. 28).

... a small knot of chillingly serious Chinese women who rarely spoke to one another, let alone anyone else. The moment they walked in, they turned on their smartphones so they could record my entire lecture. This didn't stop them from taking notes in their large spiral notebooks. They never interrupted, they never asked any questions, and the two hours were over before I knew it (Houellebecq \& Stein, 2015, p. 20).

In this context, multiple discursive hierarchies are presented. The first is the hierarchy of the senior and junior (i.e. the professor and the student). The second is the gendered hierarchy between the narrator-the male lecturer who speaks for two hours non-stopand the female students who ironically remain silent throughout the narrative. And the third is the hierarchy of different ethnic groups, in which the Chinese students are depicted as subordinate to a French (European) man who observes and laughs at their actions.

This view is highly colonial in nature, with the "colonized" being the subaltern who is unable to talk (Spivak, 1994). In this narrative, as argued by Spivak, women are shown as being unable to talk. These Chinese characters' inability to talk emerges from the hierarchies created by their ages (as juniors studying under a senior professor), gender (as women studying under a man) and ethnicity (as Asians studying under a Western European).

Lesbians are another minority group othered throughout the novel. Stereotypes about lesbians, including their physical characteristics and their behaviors, are reproduced in the novel. The following quotation provides one example.

La carrière universitaire plus d'honorable de Steve était uniquement due, toujours selon Marie Françoise, a ce qu'il broutait le minou de la mère Delouze. C'était possible, quoique surprenant. Avec ses épaules carrées, ses cheveux gris en brosse et ses cursus implacablement gender studies, Chantal Delouze, la présidente de l'Université Paris III-Sorbonne, me paraissait une lesbienne $100 \%$ brut de béton, mais je pouvais me tromper, peut être éprouvait-elle d'ailleurs une rancune envers les hommes s'exprimant par des fantasmes dominateurs.... (Houellebecq, 2015, p. 30)

The advancement of Steve's career at the university, according to Marie Françoise, was due entirely to the fact that he was eating Big Delouze's pussy. This seemed possible, albeit surprising. With her broad shoulders, her grey crew cut, and her courses in "gender studies", Chantal Delouze, the president of Paris III, had always struck me as a dyed-in-the-wool lesbian, but I could have been wrong, or maybe she bore a hatred toward men that expressed itself in fantasies of domination.... (Houellebecq \& Stein, 2015, p. 20)

The author seems to mock Chantal Delouze in his depiction of the character, and both her physical and non-physical (libidinal) desires, particularly her perceived "fantasies of [sexual] domination". Such mockery is directed towards a woman, whom the narrator believes to be either a lesbian or having the sexual desire to dominate men. Both possibilities are presented as problematic by the author, who attempts to put women in their place. They should not be lesbians, and they should be obeisant in their social and sexual relations with men.

Such mockery is also used to depict gay men and Arab women in burqas. There is an extreme perception in which all people are marked as problematic subjects. Sexuality is used by the author, through the narrator, to other them, as shown below:

Sortant de mon cours (en quoi les deux vierges en burqa pouvaient-elles être intéressées par Jean Lorrain, ce pédé dégoutant, qui se proclamait lui-même enfilantrophe? Leurs pères étaient-ils au courant du contenu exact de leur études? (Houellebecq, 2015, p. 36).

On my way out of class (what did those two virgins in burqas care about that revolting queen, that self-proclaimed analyst, Jean Lorrain? Did their fathers realize what they were reading in the name of literature? (Houellebecq \& Stein, 
2015, p. 25).

Three gendered categories are mocked in this quotation. First are the vierges ("virgins"); the Arab students dressed in burqas are mocked with a stereotype that is continuously reproduced and mocked in a French context. Second is ce pédé dégoutant ("revolting queen", i.e. gay man); the use of the word pédé ("faggot"), a vulgar term for gay men, highlights the author's distaste. The emotional content of this vulgar term is reinforced by the word dégoutant ("revolting"), which emphasizes the pejorative value of pédé. Meanwhile, the third category is identified as les pères ("the fathers" of the students), whom the narrator presents as fools for not knowing the courses taken by their daughters. All of these groups are positioned as subordinates, as minorities with severe physical and mental shortcomings. The men in this quotation are unable to escape the author's mockery, as they are not of European heritage.

\section{WHO IS THE SELF?}

Based on the above discussion, the identity of the self can be delineated and explained by finding the truth of the story. The author's diction, particularly several key words, can be used to recognize the "self", the "truth" proposed by the author. The "self" here refers to French (i.e. European) people - men, not womenas reflected in the phrase les populations authoctones d'Europe occidentale ("the indigenous population of Western Europe"). They are represented in Soumission by a male French narrator who simultaneously defines others' identities and his own self. He is neither Muslim, Jewish, nor Arabic. Although he is French, he is not a member of the National Front. He is macho, a "man's man" who enjoys and even supports patriarchy. He is an atheist, mocking all religionsIslam, Judaism, and even Christianity. He is also a brilliant intellectual, one who teaches at Sorbonne, the foremost university in France. A rationalistic logic is manifested by the author as the narrator.

Such a characterization of the "self" in the novel is reflected in the following passage:

Elle se retourna s'agenouillant sur le canapé pour examiner les rideaux, "ils sont jolis" conclut-elle finalement, "très jolis même. Mais tu as toujours eu du gout. Enfin se rassit sur le canapé pour me faire face.

"Ca ne t'ennuie pas que je te dise que tu es macho?
-Je ne sais pas, c'est peut être vraie je dois être une sorte de macho approximatif; en réalité je n'ai jamais été persuadé que ce soit une si bonne idée que les femmes puissent voter, suivre les mêmes études que les hommes, accéder aux mêmes professions, etc. (Houellebecq, 2015, p. 42).

She turned round, kneeling on the sofa to examine the curtains. "Pretty", she decided. "Very pretty, actually. But then, you always did have good taste - for such a macho man." She turned to face me. "You don't mind me calling you macho, do you?"

"I don't know, I guess I must be kind of macho. I've never really been convinced that it was a good idea for women to get the vote, study the same things as men, go into the same professions, et cetera" (Houellebecq \& Stein, 2015, p. 30).

The validation of the narrator's machismo is evident in his revival of gender discourses that have become uncommon in France. Women's rights to work, attend school, and vote in elections have been taken for granted since the feminist struggles of the 1970s. The author, through the narrator, revives these discourses as part of a broader discourse on reproduction, as reflected in the following passage:

“Tu es pour le retour au patriarcat, c'est ça?

-Je ne suis pour rien du tout, tu le sais bien mais le patriarcat avait le mérite minimum d'exister, enfin je veux dire en tant que système social il persévérait dans son être, il y avait des familles avec des enfants qui reproduisaient en gros le même schéma, bref ca tournait; là il n'y a plus assez d'enfants... (Houellebecq, 2015, p. 43).

"So you're for a return to patriarchy?"

"You know I'm not for anything, but at least patriarchy existed. I mean, as a social system it was able to perpetuate itself. There were families with children, and most of them had children. In other words, it worked, whereas now there aren't enough children, so we're finished... (Houellebecq \& Stein, 2015, p. 31).

In this passage, it is clear that the narrator approves of patriarchy because of the reproductive aspects it 
engenders. Socially, reproduction is a crucial issue for French political figures, and it has become part of French policy. Low birth rates among "indigenous" European women, who are not interested in having or raising children, have contributed to these policies.

\section{CONCLUSION}

From the above analysis of the novel Soumission, it is apparent that selfing and othering are positioned extremely in the text. This positioning is centered on a sole subject considered a "purely" French man. He is a subject characterized by his "self" and his membership in the dominant group of rational French men who are neither gay nor supporters of the National Front. $\mathrm{He}$ is a secular, even an atheist. Likewise, he is not a woman, although he does offer space for women who do not dominate men socially or sexually.

Meanwhile, many categories of "other" are presented in the novel, distinguished by their gender, ethnicities, and religions. Women, particularly those who exert sexual dominance, are positioned as lower than men. Persons with sexual orientations that are considered hors du norme ("abnormal"), namely lesbians and gays, also experience othering in the novel. Meanwhile, ethnic Chinese and Arabs are most frequently mocked in the novel, a fact that is inseparable from the stereotypes of these two ethnic groups. The Chinese (as representatives of East Asians) are narrated as passive and unwilling to argue, while Arabs are narrated at the other extremeargumentative and even aggressive. In the novel, all religions are criticized. This criticism of Islam, Judaism, and Christianity cannot be separated from secular French thoughts. The narrator understands French identity by distinguishing it from other identities.

Specific hierarchies, both gender and social, can be identified in the novel. Male supremacy, with the dominance of hegemonic masculinity, is positioned as the highest in the gender hierarchy. It serves as the subject that positions other gender identities beneath it and disempowers them (such as when discussing women who are wearing burqas). Similarly, an "indigenous" European identity depicts other groups (i.e. Chinese, Arab) as "uncivilized". A hierarchy of seniority is also strictly adhered to within the novel, and it frames relations not only between men and women but also between men; in the novel, where two male characters are of European heritage, the younger of the two occupies a lower social position.

The gender hierarchy and social categorizations in the novel are evidence of the author's efforts to create uneven power relations between specific groups within French society. In this novel, the othering process is used to position the self as the most supreme identity.

\section{ENDNOTE}

1) Bat Ye'or is a Eurabian author known for Europe-Arab Axis: Land of Islam and Islam and Dhimmitude: Where Civilisations Collide.

\section{REFERENCES}

Bauman, Z. (1991). Modernity and Ambivalence. Oxford: Basil Blackwell.

Bowen, J. R. (2009). Can Islam be French? Pluralism and Pragmatism in a Secularist State. Princeton: Princeton University Press.

Couvreur, G. (1998). Musulmans de France: Diversite, Mutations et Perspectives de l'Islam Francais. Paris: Ed de l'Atelier.

Eurostat Statistics Explained. (2017, April 10). Immigration by Citizenship 2015. Retrieved from http://ec.europa.eu/eurostat/ statisticsexplained/index.php/File:Immigration by citizenship, 2015 .

Heinsh, R. (2016). Paul and the Gentile Problem. Journal of Beliefs and Values, 37 (3), pp. 357-359.

Houellebecq, M. (2015). Soumission. Paris: Flamarion.

Houellebecq, M. \& Stein, L. (2015). Submission. London: Vintage.

INSEE. (2005). Population Census 1999. Les Immigres En France (Immigrants in France).

Kastoryano, R. (2004). Religion and Incorporation: Islam in France and Germany. International Migration Review, 38 (3), pp. 1234-1255. https:// doi.org/10.1111/j.1747-7379.2004.tb00234.

Leger, N. (2015). Le Droit a l'Irresponsabilite. Esprit, 41-44.

Mandel, M. S. (2014). Muslims and Jews in France: History of Conflict. Princeton: Princeton University Press.

McAlpin, H. (2015, October 20). Don't Take 'Submission' Lying Down. National Public Radio. Retrieved from http://www.npr.org/2015/10/20/448977012/ don't-take-submission-lying-down.

Mustofa, A. (2016). Resistesi-Negosiasi Identitas Islam dan Non-Islam dalam Soumission Karya Michel Houellebecq. (Unpublished Master Thesis). Universitas Gadjah Mada, Yogyakarta.

Perez, C. (2012). Houellebecq, le Vingt-Heures et l'Art du Roman: A propos de Soumission. Revue 
Critique de Fixxion Francaise Contemporaine, 4, pp. 112-120.

Pramudita, K. (2013). Resistensi Kritik dalam L'Homme Rompu Karya Tahar Ben Jelloun (Unpublished Master Thesis). Universitas Gadjah Mada, Yogyakarta.

Sentana, Y. M. (2016). The Lure of Image: Kebohongan pada Narasi Perempuan dalam Syngue Sabour Pierre de Patience Karya Atiq Rahimi (Unpublished Master Thesis). Universitas Gadjah Mada, Yogyakarta.
Spivak, G. C. (1994). Can the Subaltern Speak? In Colonial Discourse and Post-Colonial Theory (ed) Patrick Williams and Laura Chrisman. Hertfordshire: Harvester Wheatsheaf.

Udasmoro, W. (2017). Language Construction in French Contemporary Discourses. Indonesian Journal of Islam and Muslim Societies, 7 (1), pp. 77-99. https://doi.org/10.18326/ijims.7il.77.99.

Zwilling, A.-L. (2015). A Century of Mosques in France: Building Religious Pluralism. International Review of Sociology, 25 (2), pp. 333-340. https:// doi.org/10.1080/03906701.2015. 